\title{
BITWA POD KUMANOWEM NA ŁAMACH GAZETY „POLITIKA” - MIT UMACNIAJĄCY POZYCJĘ POLITYCZNĄ KRÓLA ALEKSANDRA I KARADJORDJEVICIA
}

\author{
PAWE€ MichalAK
}

\begin{abstract}
Paweł Michalak, Bitwa pod Kumanowem na tamach gazety „Politika” - mit umacniajacy pozycje politycznq króla Aleksandra Karadjordjevicia (The battle of Kumanovo in the newspaper „Politika”, as a myth strengthening political position of king Aleksander Karadjordjević)
\end{abstract}

Balcanica Posnaniensia. Acta et studia, XIX, Poznań 2012, Wydawnictwo Instytutu Historii UAM, pp. 169-179, ISBN 978-83-63-047-17-7, ISSN 0239-4278. Polish text with a summary in English.

Paweł Michalak, Uniwersytet im. Adama Mickiewicza, Instytut Historii, ul. Św. Marcin 78, 61-809 Poznan, Polska - Poland.

[...] Ponury i ciężki był dzień pogrzebu króla Aleksandra. [...] Szliśmy przez 4 godziny w kondukcie za trumną ulicami Belgradu na dworzec. Gdzie spojrzeć klęczały płaczące tłumy. Wzruszający był widok żołnierzy, którzy w długich szpalerach prezentując broń nie mogli ocierać łez płynących im po policzkach. [...] W powrotnej drodze z Oplenac widzieliśmy aż po krańce horyzontu tłumy dalej klęczące, dalej płaczące, niechcące się rozejść, jakby nie miały gdzie iść i po co $[\ldots]^{1}$.

W ten sposób polski dyplomata Władysław Günther-Schwarzburg opisał okoliczności pogrzebu króla Aleksandra I Karadjordjevicia, zamordowanego 9 października 1934 r. w Marsylii. Choć oczywiście nie wszyscy obywatele Królestwa Jugosławii darzyli swojego władcę aż tak wielką miłością i oddaniem, jak przedstawił to polski poseł w Belgradzie, to jednak należy przyznać, że młodszy z synów króla Piotra I Karadjordjevicia cieszył się sporą i autentyczną sympatią części z nich. Popularność tą zawdzięczał, jak się wydaje, trzem powiązanym ze sobą czynnikom.

Pierwszym z nich był charakter króla, który uchodził za prawego, honorowego, szczerego i przede wszystkim spokojnego, by nie rzec zrównoważonego człowieka. W porównaniu ze starszym bratem, Jerzym, który zrzekł się na jego korzyść pretensji do tronu (27 marca 1909 r. $^{2}$ ), wydawał się być idealnym kandydatem na przyszłego władcę.

\footnotetext{
${ }^{1}$ W. Günther, Pióropusz i szpada. Wspomnienia ze stużby zagranicznej, Paryż 1963, s. 136-137.

2 Б. Глигоријевић, Краљь Александар Карађорђевић, књ. I, Београд 2010, s. 24-25.
} 
Drugim czynnikiem były jego niemałe dokonania na polu militarnym, zarówno w czasie wojen bałkańskich (szczególnie pierwszej), jak i w czasie I wojny światowej. Aleksander, jako młodszy z synów króla Piotra, od początku swojej edukacji przygotowywany był do roli oficera i dyplomaty, a nie polityka - króla ${ }^{3}$. To w mundurze czuł się najlepiej i właśnie na polu wojskowym odnosił największe sukcesy. Jako dowódca I Armii brał udział w stoczonej w dniach 23-24 października 1912 r. bitwie pod Kumanowem, uważanej za jedną z najważniejszych bitew I wojny bałkańskiej. Poza sukcesem militarnym, jakim było dla armii serbskiej otworzenie drogi w kierunku Macedonii, zwanej też Serbią Południową i wyparcie Turków z tych terenów, równie wielkim, o ile nie większym było zwycięstwo moralne, jakie przypadło Serbom. Bitwa ta okazała się pierwszą poważną próbą sił serbskiej armii, a odniesione zwycięstwo okazało się być bezcennym kapitałem podnoszącym jej morale ${ }^{4}$. Nie przypadkowo określano ją mianem zemsty za bitwę na Kosowym Polu. Bitwa pod Kumanowem urosła niemalże do miana swoistej bitwy założycielskiej dla nowej Serbii, bitwy, dzięki której odzyskano tereny tak silnie związane z serbską tożsamością narodową jak Kosowo, czy też Macedonia (Skopje było wszakże stolicą państwa założonego przez cara Stefana Duszana). Zwycięstwo to było również pierwszym tak znaczącym sukcesem dynastii Karadjordjeviciów, która bardzo sprawnie wykorzystywała ten fakt dla budowania własnego wizerunku w oczach poddanych.

Niewątpliwie największym zwycięzcą tej bitwy był następca tronu, Aleksander Karadjordjević, dowódca I Armii, która przypuściła główne uderzenie na tureckie pozycje. Choć naczelnym dowódcą sił serbskich, w czasie obu wojen bałkańskich, był szef sztabu generalnego, generał Radomir Putnik (który po bitwie pod Kumanowem, wraz ze swoim zastępcą Živojinem Mišiciem, został awansowany przez króla Piotra I Karadjordjevicia do stopnia vojvody - odpowiadającego stopniu generała armii ${ }^{5}$ ), to właśnie jego podkomendny, zaledwie 24-letni wówczas książę Aleksander, zyskał sobie miano „wielkiego wyzwoliciela Serbów”. Należy jednak podkreślić, że z militarnego punktu widzenia książę nie wyróżnił się niczym wybitnym, a na ostateczne zwycięstwo jego armii złożyło się kilka czynników.

Bitwa pod Kumanowem była tak naprawdę atakiem prewencyjnym tureckiej Armii Wardarskiej z zamiarem rozbicia najpotężniejszej, kroczącej w głąb Macedonii, I Armii serbskiej poprzez atak z zaskoczenia, zanim połączy się ona z II i III Armią, maszerującymi odpowiednio z terenów południowo-zachodniej Bułgarii oraz Kosowa ${ }^{6}$. Początkowo wydawało się, że manewr ten zakończy się powodzeniem.

Po pierwszym dniu walk, Zeki pasza, dowódca Armii Wardarskiej miał stwierdzić, że ,jak dotąd armia osmańska ma przewage" "7. Punktem zwrotnym, który w praktyce przesądził o wyniku bitwy było przybycie pod Kumanowo tych dywizji I Armii,

\footnotetext{
${ }^{3}$ Ibidem, s. 26-27.

${ }^{4}$ E.J. Erickson, Defeat in Detail. The Ottoman Army in the Balkans, 1912-1913, London 2003, s. 181 .

${ }^{5}$ R.C. Hall, The Balkan Wars. Prelude to the First World War, London 2002, s. 48.

${ }^{6}$ Ibidem, s. 47-49; E.J. Erickson; Defeat in Detail, s. 181.

${ }^{7}$ R.C. Hall, The Balkan Wars, s. 48.
} 
które pierwszego dnia bitwy nie zdażyły wziąć w niej udziału. Ich absencja spowodowana była zaskoczeniem, jakim był turecki atak na nieprzygotowaną, maszerującą w rozluźnionym szyku armię serbską. Nie bez znaczenia dla ostatecznego zwycięstwa Serbów był też fakt upadku morale części żołnierzy osmańskich, szczególnie Albańczyków ze Skopijskiej Dywizji Piechoty, którzy na wieść o zdobyciu Prištiny przez III Armię (pod dowództwem generała Božidara Jankovicia) i jej dalszym pochodzie na Skopje, zdezerterowali i ruszyli bronić miasta ${ }^{8}$.

Doskonałym argumentem, potwierdzającym częściowy brak kontroli księcia Aleksandra nad wydarzeniami rozgrywającymi się pod Kumanowem, jest fakt, że dowództwo I Armii nie dowodziło bezpośrednio tymi działaniami. Prawdopodobnie jeszcze na początku drugiego dnia walk sądzono, że nie jest to walna bitwa z siłami tureckimi, a jedynie drobna potyczka z forpocztą Armii Wardarskiej, której koncentracji spodziewano się na równinie Owczego Pola w pobliżu Skopje?.

Mimo to sukcesy armii serbskiej w tej i kolejnych bitwach wojen bałkańskich, obok innej działalności Aleksandra Karadjordjevicia jako regenta Królestwa Serbii (od 24 czerwca 1914 r. $^{10}$ ) w czasie ,wielkiej wojny” okazały się być wydarzeniami, które przyniosły mu bardzo duży prestiż ${ }^{11}$.

Ważnym czynnikiem, przyczyniającym się do dużej popularności Aleksandra wśród poddanych, było sprawne wykorzystanie jego działań do kreowania własnego wizerunku. Przedstawianie go, jako uczciwego, honorowego i prostolinijnego żołnierza, walczącego w obronie ojczyzny oraz o wyzwolenie wszystkich Słowian Południowych, okazało się być skuteczną metodą pozyskiwania sympatii poddanych, metodą, którą zaczęto stosować na szerszą skalę po objęciu tronu przez Aleksandra Karadjordjevicia 16 sierpnia $1921 \mathrm{r}$.

Zadanie to byłoby jednak utrudnione bez wsparcia prasy, która na początku XX wieku wciąż pozostawała najbardziej popularnym i zdecydowanie najłatwiej dostępnym nośnikiem informacji. Największą i najpopularniejszą gazetą w Królestwie Serbów, Chorwatów i Słoweńców (od 1929 r. zaś Jugosławii) był dziennik „Politika”. Pismo to, założone przez Vladislava Ribnikara 25 stycznia 1904 roku w Belgradzie, uważane było za jedną z najstarszych i cieszących się największym prestiżem gazet codziennych na Bałkanach ${ }^{12}$. W okresie rządów Aleksandra I (1921-1934), „Politika”, której redaktorami naczelnymi byli w tym czasie: Miomir Milenović i Jovan Tanović, uchodziła za najbardziej opiniotwórczą gazetę w Królestwie. Pod

8 Б. Ратковић, М. Ђуришић, С. Скоко, Србија и Црна Гора у Балканским Ратовима, Београд 1972, s. 78-83.

9 Ibidem, s. 76-77.

10 Д. Р. Живојиновић, Краљ Петар I Карађорђевић, књ. III, Београд 2009, s. 1-2.

11 Б. Глигоријевић, Крал Александар, s. 88-89.

$12 \mathrm{http} / /$ www.politika-ad.com/index.php?option=com_content\&view=article\&id=19\&Itemid $=31 \&$ lang=cirilica [dostęp na 14.10.2012]. 
koniec lat dwudziestych była ona tytułem o największym dziennym nakładzie, wynoszącym ok. 75000 egzemplarzy (przy 60000 „Vreme” i 25000 „Prawdy”) ${ }^{13}$.

Mimo głoszonej powszechnie apolityczności, gazeta ta wspierała oficjalną linię polityczną króla i rządu ${ }^{14}$. Bardzo ciekawym aspektem tej działalności jest sposób przedstawiania przez nią wydarzeń związanych z upamiętnianiem bitwy pod Kumanowem. Na kultywowaniu tego swoistego „mitu kumanowskiego” niewatpliwie zależało królowi, który w obliczu ciągłych kłopotów i sporów targających polityką wewnętrzną kraju, chciał uchodzić za „Zjednoczyciela” (zaczął być zresztą takim przydomkiem określany), żołnierza i bohatera, któremu obce były rozgrywki partyjne. Spora część poddanych tak właśnie go postrzegała.

Pierwszą nadarzającą się okazją, która mogła posłużyć temu celowi, były obchody dziesiątej rocznicy wybuchu I wojny bałkańskiej, co za tym idzie również bitwy pod Kumanowem. Równo dziesięć lat po jej rozpoczęciu, 23 października 1922, „Politika” poświęciła niemal cały numer temu wielkiemu zwycięstwu. Autorzy artykułów nakreślili plan taktyczny bitwy, przedstawili stan serbskiej i tureckiej armii oraz opisali jej przebieg. Co ciekawe, za głównego ojca tego sukcesu uznano (notabene słusznie) Radomira Putnika. Jego fotografia, na której towarzyszy on królowi Piotrowi I, umieszczona została na pierwszej stronie numeru ${ }^{15}$. Na kolejnych przedstawiono fotografie dowódców poszczególnych dywizji i pułków biorących udział $\mathrm{w}$ bitwie ${ }^{16}$. Warto zauważyć, że $\mathrm{w}$ tym numerze pominięta została całkowicie postać króla Aleksandra, którego fotografii nie umieszczono nawet wśród wyżej wspomnianych, mimo iż przedstawieni na nich dowódcy podlegali mu bezpośrednio, jako dowódcy I Armii. Wyraźnie skupiono się na podkreśleniu bohaterstwa zwykłych żołnierzy i olbrzymiego znaczenia samej bitwy, zarówno w aspekcie militarnym, jak również, a może przede wszystkim, mentalnym. Podkreślono, że bitwa miała decydujące znaczenie nie tylko dla dalszych wydarzeń na serbskim odcinku frontu, ale również dla działań wojennych prowadzonych przez armię bułgarską, która odtąd mogła całkowicie skupić się na działaniu w Tracji, nie martwiąc się, że Turcy zaatakująją od tyłu i zagrożą niemal zupełnie niechronionej Sofii ${ }^{17}$. Drugim, równie ważnym aspektem zwycięstwa odniesionego pod Kumanowem, miało być, według redakcji gazety, zwiększenie morale serbskich żołnierzy i całego społeczeństwa. Okazało się, że młode państwo było w stanie pokonać armię potężniejszego, jak się wydawało, wroga ${ }^{18}$.

Dopiero w numerze opublikowanym następnego dnia, 24 października 1922 r., dziennikarze „Politiki” zwrócili większą uwagę na rolę, jaką ówczesny król odegrał w wydarzeniach sprzed dziesięciu lat. Pretekstem do podkreślenia zasług Aleksandra było sprawozdanie $\mathrm{z}$ obchodów rocznicowych w Kumanowie, w których osobisty

13 C. Nielsen, One State, One Nation, One King: The Dictatorship of King Aleksandar and his Yugoslav Project 1929-1935, Columbia University 2002 [ nieopublikowana praca doktorska], s. 337.

14 Ibidem.

15 „Политика”, бр. 5208, 23.10.1922 r., s. 1.

16 Ibidem, s. 2-4.

17 Ibidem, s. 3.

18 Ibidem. 
udział wzięła rodzina królewska wraz z zaproszoną królową Grecji Elżbietą, żoną króla Jerzego II i siostrą małżonki Aleksandra - Marii ${ }^{19}$. Choć w przytoczonym przez autorów tekście przemówienia, wójt gminy Kumanowo nie zapomniał o wkładzie poszczególnych generałów i zwykłych żołnierzy, którzy przyczynili się do tego historycznego zwycięstwa, to jednak ewidentnie najważniejszą częścią jego mowy był fragment, w którym odniósł się bezpośrednio do króla, nazywając go wprost „bohaterskim Oswobodzicielem", podkreślając zasługi władcy przez stwierdzenie, że „Kumanowo jest pięknym, szlachetnym kamieniem w Jego Królewskiej Koronie”20. Warto też zauważyć, że sam Aleksander również nie odcinał się od tego typu sformułowań. W swej przemowie do oficerów oddał szacunek żołnierzom, podkreślając jednak, że to pod jego dowództwem I Armia odniosła wielkie zwycięstwo, które otworzyło Serbii drogę do Macedonii, przesądzając w zasadzie losy kampanii, której ostatecznym zwieńczeniem było zwycięstwo jego wojsk w bitwie pod Bitolą

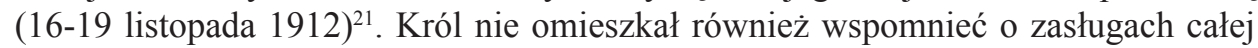
jego dynastii, kończąc swą przemowę słowami: , I tak walka rozpoczęta w 1804 r. pod przywództwem mojego sławnego pradziada, zakończyła się w 1912 r."22.

Nie ulega wątpliwości, że Aleksander próbował wykorzystać obchody zwycięstwa nad turecką armią do przedstawienia siebie jako kontynuatora dzieła rozpoczętego przez legendarnego Jerzego Czarnego. Bardzo ważnym elementem w kreowaniu tego wizerunku było również podkreślenie, iż zwycięstwo pod Kumanowem, a w dalszej kolejności, w obu wojnach bałkańskich, było tak naprawdę pierwszym krokiem, umożliwiającym wprowadzenie w życie idei utworzenia wspólnego państwa wszystkich Słowian Południowych.

Również dziennikarze „Politiki” pomagali w kreowaniu takiego wizerunku władcy, kończąc relacje z obchodów podsumowaniem, w którym stwierdzono wprost, że: „Pod mądrymi rządami Jego Królewskiej Mości Aleksandra, zarówno na polu politycznym, jak i wojskowym, możemy mieć nadzieję i pewność co do lepszej przyszłości naszej silnej i potężnej Ojczyzny"23.

Bardzo interesującym zabiegiem było przedstawienie wkroczenia Aleksandra na czele I Armii do Skopje (26 października 1912), jako rezultatu bitwy pod Kumanowem. Podkreślano, że to właśnie ówczesny książę odzyskał „duszanową stolicę” i przyłączył ją do macierzy ${ }^{24}$. Jak wspomnieli autorzy artykułu: „26 października 1912 r. był dniem pochmurnym i deszczowym, jednak, gdy tylko I Armia z następcą tronu wkroczyła do miasta, deszcz przestał padać, a na niebie pojawiły się nieznaczne promienie jesiennego słońca"25. Wkroczenie Aleksandra do Skopje przedstawiane jest niemalże jako starożytny triumf i wielki sukces następcy tronu, którego ukazywano jako

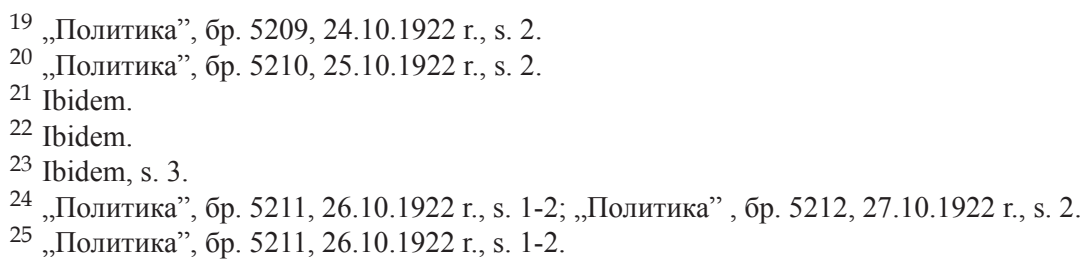


wybawiciela: „[...] zachwycony lud zasypywał kwiatami ulice, po których szedł on 'Królewski Syn' ${ }^{26 ”}$ Na zakończenie artykułu skonkludowali zaś: „W ten sposób zakończył się jeden z największych i najradośniejszych dni w naszej najnowszej historii, dzień wkroczenia do Skopje, starej duszanowej stolicy"27.

Wydaje się, że odwoływanie się do dziedzictwa państwa cara Stefana Duszana nie było przypadkowe. Jeszcze dobitniej podkreślało zasługi króla w wyzwoleniu Słowian Południowych spod tureckiego jarzma i w utworzeniu nowego, wspólnego państwa. Odnosząc się do słów dziennikarzy: „Kumanowo zapoczątkowało nową epokę ${ }^{28}$.

Podobny sposób przedstawiania znaczenia bitwy pod Kumanowem oraz roli, jaką odegrał w niej król Aleksander I Karadjordjević, utrzymywał się w zasadzie przez cały okres jego rządów. W latach 1922-1934, niemal corocznie, mniej więcej w okolicach 23-27 października pojawiały się na łamach „Politiki” relacje z obchodów rocznicowych, zarówno w samym Kumanowie ${ }^{29}$ (gdzie między innymi, w 1927 r., w celu upamiętnienia wydarzeń z 1912 r. miejscowe koszary zostały nazwane imieniem Króla Aleksandra $\mathrm{I}^{30}$ ), jak w okolicznych miejscowościach, np. we wsi Mlado Nagoričane $\mathrm{e}^{31}$, czy Skopje 32 ( w którym z kolei w 1927 r. na pamiątkę piętnastolecia oswobodzenia, miejscowy teatr został nazwany imieniem króla Aleksandra $\mathrm{I}^{33}$ ).

Odstępstwami od tej reguły są lata 1925, 1929, 1933 i 1934, w których „Politika” nie zamieściła na swych łamach żadnych informacji na temat obchodów kolejnych rocznic bitwy pod Kumanowem.

W 1925 r., taki stan rzeczy wynikał prawdopodobnie z bardzo dużej liczby ważnych zdarzeń, rozgrywających się zarówno w polityce wewnętrznej państwa, jak i na arenie międzynarodowej, które skutecznie absorbowały uwagę dziennika. Rok 1925 zanosił się na przełomowy dla całego systemu parlamentarnego Królestwa SHS. W dniu 18 lipca tego roku, radykałowie Nikoli Pašicia uformowali rząd, w którego skład weszli po raz pierwszy przedstawiciele największej partii opozycyjnej - Chorwackiej Partii Chłopskiej (HSS - Hrvatska Seljačka Stranka), na czele ze Stjepanem Radiciem, który objął resort oświaty ${ }^{34}$. Nic dziwnego, więc, że kwestie parlamentarne budziły wówczas większe zainteresowanie ${ }^{35}$. Poza tym, w dniach 5-16 października 1925, odby-

26 Ibidem.

27 Ibidem.

28 „Политика”, бр. 5568, 24.10.1923 r., s. 3-4.

29 "Ibidem; „Политика”, бр. 5928, 25.10.1924 r., s. 4; „Политика”, бр. 6646, 25.10.1926 r., s. 3; „Политика”, бр. 7002, 25.10.1927 r., s. 5; „Политика”, бр. 8427, 25.10.1931 r., s. 4.

30 „Политика”, бр. 7002, 25.10.1927 r., s. 5.

31 „Политика”, бр 8076, 24.10.1930 r., s. 5; „Политика”, бр. 8784, 24.10.1932 r., s. 4.

32 „Политика”, бр. 6651, 30.10.1926 r., s. 4; „Политика”, бр. 7003, 26.10.1927 r., s. 6; „Политика”, бр. 7354, 20.10.1928 r., s. 3; „Политика”, бр. 7361, 27.10.1928 r., s. 6; „Политика”, бр. 8079, 27.10.1930 r., s. 8; „Политика”, бр. 8429, 27.10.1931 r., s. 6.

33 „Политика”, бр. 7003, 26.10.1927 r., s. 6.

34 В. Ћоровић, Историја српског народа, књ. III, Београд 1997, s. 461-463.

35 „Политика”, бр. 6282, 20.10.1925, s. 2-3; „Политика”, бр. 6283, 21.10.1925, s.3; „Политика”, бр. 6284, 22.10.1925, s. 2-3; „Политика”, бр. 6285, 23.10.1925, s. 2-4; „Политика”, бр. 6287, 25.10.1925, s. 3 . 
ła się konferencja w Locarno ${ }^{36}$, a 19 października wybuchł grecko-bułgarski konflikt graniczny, tzw. incydent w Petriču (znany też jako „wojna o bezpańskiego psa”), który trwał do 29 dnia tego miesiąca ${ }^{37}$. Wydaje się, że kombinacja tych zdarzeń spowodowała, iż „Politika” całkowicie pominęła obchody bitwy pod Kumanowem.

W roku 1929, jak się wydaje, głównym powodem braku zainteresowania dziennikarzy belgradzkiego dziennika rocznicą bitwy kumanowskiej było ogłoszenie 3 października 1929 r. dekretu królewskiego, zmieniającego oficjalnie nazwę państwa na Królestwo Jugosławii oraz likwidującego 33 oblasti na rzecz 9 nowych banovin $^{38}$. Prawdopodobnie to przede wszystkim z powodu informowania społeczeństwa o wprowadzonych zmianach obchody bitwy pod Kumanowem zostały pominięte ${ }^{39}$. Również w 1933 r. sprawy wewnętrzne państwa odciągnęły uwagę dziennikarzy od upamiętnienia wydarzeń z 1912 r. Z kolei rok później, 9 października krajem wstrząsnęła wiadomość o zabójstwie króla. Obchody kolejnych rocznic odeszły na drugi plan.

Jak już wspomniano, poza wymienionymi wyjątkami, belgradzki dziennik co roku publikował artykuły związane z działalnością króla Aleksandra na froncie macedońskim. Warto zauważyć jednak, że po 1925 r., a więc po przesileniu parlamentarnym, po którym sytuacja w polityce wewnętrznej państwa systematycznie się pogarszała, „Politika” coraz większy nacisk kładła nie tyle na samo upamiętnienie bitwy, co na przedstawienie w możliwie najjaśniejszym świetle postaci króla Aleksandra. Starano się przede wszystkim pokazać, jaką miłością i wdzięcznością darzyli go mieszkańcy tzw. Serbii Południowej, a więc terenów wyzwolonych przez niego dzięki zwycięstwu pod Kumanowem. Odtąd niemal co roku „Politika” drukowała artykuły przedstawiające dobroduszność i prostotę króla, który chętnie sam wychodził do ludzi, by z nimi porozmawiać, lub pomagać im, choćby finansowo ${ }^{40}$. Przykładami mogą tu być publikacje z 26 października 1926 r., kiedy to gazeta opublikowała informacje o finansowym wsparciu (10 000 dinarów), którego król udzielił napotkanym w czasie podróży po Kosowie, pogorzelcom z miejscowości Suva Reka ${ }^{41}$, czy też publikacja z 28 października 1926 r., opisująca sytuację, kiedy to król podwiózł samochodem do Prizernu moknącego na drodze żołnierza, który oczywiście początkowo nie rozpoznał władcy ${ }^{42}$.

36 „Политика”, бр. 6283, 21.10.1925, s. 1; „Политика”, бр. 6285, 23.10.1925, s. 1.

37 „Политика”, бр. 6284, 22.10.1925, s. 3 „Политика”, бр. 6285, 23.10.1925, s. 5 „Политика”, бр. 6286, 24.10.1925, s. 1-2; „Политика”, бр. 6287, 25.10.1925, s. 2 „Политика”, бр. 6288, 26.10.1925, s. 1-2; „Политика”, бр. 6289, 27.10.1925, s. 1-2; „Политика”, бр. 6290, 28.10.1925, s. 1-2; „Политика”, бр. 6291, 29.10.1925, s. 1-2; „Политика”, бр. 6292, 30.10.1925, s. 1-4.

38 В. Ћоровић, Историја српског народа, књ. III, s. 468.

39 „Политика”, бр. 7694, 04.10.1929, s. 1-3; „Политика”, бр. 7695, 05.10.1929, s. 1-4; „Политика” , бр. 7715, 25.10.1929, s. 4.

40 „Политика”, бр. 6647, 26.10.1926 r., s. 4; „Политика”, бр. 7002, 25.10.1927 r., s. 5; „Политика”, бр. $7355,21.10 .1928$ r., s. 6 .

41 „Политика”, бр. 6647, 26.10.1926 r., s. 4.

42 „Политика”, бр. 6645, 28.10.1926 r., s. 6. 
W okresie po 1925 r., Aleksander przedstawiany jest niemalże jako troskliwy ojciec, który martwi się z osobna o każdego ze swych poddanych, jak chociażby o czterech braci, młodych pasterzy, których spotkał podczas wizyty w okolicach Bitoli w październiku 1928 r. Jak podaje „Politika”, król tak przejął się ich losem, że podarował im 1000 dinarów i zaproponował, że jednemu z nich mógłby nawet pomóc w dostaniu się do szkoły podoficerskiej ${ }^{43}$.

Po 1929 r., a więc po wprowadzeniu dyktatury (6 stycznia 1929 r.), sposób, w jaki przedstawiano króla nie uległ zmianie, nadal podkreślano jego rolę w wyzwoleniu części kraju spod panowania tureckiego oraz troskę o rozwój cywilizacyjny państwa. Jedyną zauważalną różnica, która miała zapewne na celu wzmocnienie pozycji króla, było położenie większego nacisku na przedstawienie zwycięstwa pod Kumanowem, jako jednego z pierwszych kroków do stworzenia Jugosławii. Potwierdzeniem tego może być przytoczona 24 października 1930 r. opinia jednego z kumanowskich oficjeli, biorącego udział w obchodach upamiętniających wydarzenia z 1912 r., który zasugerował, że tak, jak razem z I Armią pod Kumanowem, tak i teraz król Aleksander pokona wszelkie trudności stojące przed Jugosławią ${ }^{44}$.

Dwudziesta rocznica wybuchu wojen bałkańskich, przypadająca na październik 1932 r., przyciągnęła naturalnie większą uwagę dziennikarzy. Już 30 września, a więc w rocznicę ogłoszenia przez króla Piotra I rozkazu mobilizacji wojska, „Politika” rozpoczęła cykl „Przed dwudziestu laty” („Pre dvadeset godina”), który polegał na przedruku informacji i artykułów opublikowanych 20 lat wcześniej na łamach belgradzkiego dziennika ${ }^{45}$.

W dwudziestą rocznicę rozpoczęcia serbsko-tureckich walk pod Kumanowem (23 października 1932 r.), „Politika” poświęciła temu wydarzeniu całą stronę. Wysławiając męstwo i odwagę żołnierzy, którzy, jak podkreślali dziennikarze, pokazali w tej bitwie całą wartość serbskiej armii, po raz kolejny pamiętano również o podkreśleniu roli króla Aleksandra. Chociaż byłemu przywódcy I Armii nie zostało w tym artykule poświęcone nawet jedno zdanie, to jednak jego fotografia, umieszczona w centralnym punkcie rozkładówki, jednoznacznie narzucała skojarzenie, komu Serbowie w tej bitwie najwięcej zawdzięczali ${ }^{46}$. Następnego dnia, 24 października 1932 r., obok dalszej części cyklu „Przed dwudziestu laty”, autorzy umieścili dwa krótkie artykuły, będące relacją ze współczesnych im rocznicowych obchodów w Mlado Nagoričane, tj. na przedmieściach Kumanowa oraz w samym Kumanowie ${ }^{47}$. Bardzo ważną, mimo że krótką, to jednak stanowiącą doskonałe uzupełnienie historycznego opisu wydarzeń, jest publikacja telegramu wysłanego przez wójta gminy Kumanowo, Ćire Manevicia do Jego Królewskiej Mości. Urzędnik ten podkreślił, że bitwa pod Kumanowem była historycznym i najchwalebniejszym zwycięstwem serb-

\footnotetext{
43 „Политика”, бр. 7356, 22.10.1928 r., s. 5.

44 „Политика”, бр. 8076, 24.10.1930, r. s. 5.

45 „Политика”, бр. 8760, 30.09.1932 r., s. 1.

46 „Политика”, бр. 8783, 23.10.1932 r., s. 5.

47 „Политика”, бр. 8784, 24.10.1932 r., s. 4.
} 
skiego narodu, do którego przyczyniło się roztropne dowództwo ówczesnego księcia Aleksandra. Zwycięstwo to, uwolniło naród spod tureckiego jarzma, za co obywatele zawsze będą królowi wdzięczni ${ }^{48}$. Wydaje się, że właśnie tymi słowami kumanowskiego urzędnika posłużyli się dziennikarze „Politiki”, by podkreślić raz jeszcze wielkie zasługi króla.

Obchody dwudziestolecia wybuchu I wojny bałkańskiej okazały się być swoistą klamrą kończącą coroczną, zapoczątkowaną 19 października 1922 r., serię artykułów poświęconych tej kwestii, jednak jak zaznaczono, przez niemal dziesięć lat stanowiły stale pojawiający się na łamach „Politiki” element.

Choć królowi Aleksandrowi I Karadjordjeviciowi nie można całkowicie odbierać zasług za jego działalność w czasie wojen bałkańskich, to nie ulega watpliwości, iż dziennikarze „Politiki” dbali o to, by poddani o zasługach tych nie zapominali. Wydaje się jednak, iż nie będzie nadużyciem stwierdzenie, że belgradzki dziennik wydatnie przyczynił się do wykreowania swoistego „mitu kumanowskiego”, przedstawiającego króla jako wielkiego wyzwoliciela i obrońcę najsłabszych. Zabiegami, które ewidentnie pomogły w tej kreacji były: odpowiednia retoryka i przedstawienie zwycięstwa w bitwie pod Kumanowem i dalszych, wynikających z tego faktu wydarzeń, jako zemsty za bitwę na Kosowym Polu, nawiązania do dziedzictwa cara Stefana Duszana oraz kontynuacji dzieła rozpoczętego przez pradziada króla Jerzego Czarnego. Należy zwrócić również uwagę na słownictwo, którego używali dziennikarze. „Heroiczny, ukochany Król Aleksander I”49, „oswobodziciel ${ }^{50 ”, ~ k t o ́ r e g o ~}$ armia „otworzyła wrota wolności” ${ }^{51}$, „przecięła łańcuch niewoli krępujący nas przez stulecia" ${ }^{52}$, to tylko przykładowe sformułowania, które wydają się potwierdzać sposób w jaki dziennikarze „Politiki” chcieli przedstawić władcę.

Należy jednak uczciwie zaznaczyć, że „Politika” nie była typową „tubą propagandową", zakłamującą rzeczywistość i wręcz nachalnie narzucającą jedynie słuszny światopogląd. Wkład dziennika w stworzenie mitu, który niewątpliwie był bardzo przydatny królowi, polegał na umiejętnym przedstawianiu faktów i ukazywaniu ich w odpowiednim kontekście. Częstokroć wystarczyło jedynie przytoczyć wypowiedź przedstawicieli administracji, bądź to Kumanowa, bądź Skopje, którzy rokrocznie opiewali zasługi Aleksandra. Jedynie artykuły przedstawiające króla, jako niemalże troskliwego ojca, któremu nie był obojętny los żadnego ze swoich poddanych, wydają się być wyraźnie naciaganą propagandą.

Warto jeszcze zastanowić się, dlaczego Aleksandrowi I zależało na stworzeniu „mitu kumanowskiego”? Odpowiadając na to pytanie należy odnieść się przede wszystkim do dwóch kwestii.

\footnotetext{
48 Ibidem.

49 „Политика”, бр. 5211, 26.10.1922 r., s. 1-2.

50 „Политика”, бр. 5210, 25.10.1922 r., s. 2.

51 „Политика”, бр. 8429, 27.10.1931 r., s. 6.

52 „Политика”, бр. 7002, 25.10.1927 r., s. 5.
} 
Po pierwsze, był on pomocny w uzyskaniu możliwie największej sympatii wiernej i lojalnej ludności, przywiązanej do króla i jego rodziny, co było niezwykle cennym czynnikiem, wspierającym pozycję polityczną króla. Poza tym okazało się być kapitałem, który zaprocentował w przyszłości. Nie ulega wątpliwości, że gdyby nie sympatia i poparcie części poddanych, wspierających działania króla, wprowadzenie dyktatury 6 stycznia 1929 r., byłoby o wiele trudniejsze, o ile w ogóle możliwe.

Drugim powodem, dla którego kreowano wizerunek króla, jako wyzwoliciela Macedonii, gospodarza i troskliwego ojca zarazem, była zapewne skomplikowana i cały czas niestabilna sytuacja w tej części kraju, wynikająca z rywalizacji zwolenników i działaczy WMRO (Wewnętrznej Macedońskiej Organizacji Rewolucyjnej) z obecnymi władzami. Królowi Aleksandrowi z pewnością zależało na podkreśleniu swoich zasług dla tej części Królestwa, by umocnić na tych ziemiach swoją, a co za tym idzie, również serbską pozycję polityczną.

Na zakończenie należy stwierdzić, że choć w sposobie, w jaki dziennikarze „Politiki” przedstawiali bitwę pod Kumanowem i wszelkie związane z nią obchody rocznicowe, widoczna jest chęć wyraźnego podkreślenie zasług i roli, jaką w tym wydarzeniu odegrał król Aleksander I Karadjordjević, to jednak trzeba podkreślić, iż działanie to nie było całkowicie pozbawione podstaw. Prawnuk Jerzego Czarnego zapisał się w dziejach, jako bardzo dobry wojskowy, którego umiejętności zostały pozytywnie zweryfikowane, tak przez wojny bałkańskie, jak i przede wszystkim, I wojnę światową. Jak się okazało, Aleksander był równie dobrym politykiem. Cechą zaś dobrego polityka jest umiejętne wykorzystywanie chwalebnych kart swojego życiorysu w rozgrywkach politycznych. Królowi Aleksandrowi z pewnością się to udało, a bitwa pod Kumanowem wciąż kojarzona jest niejako automatycznie z postacią króla Aleksandra I Karadjordjevicia - Zjednoczyciela.

\author{
THE BATTLE OF KUMANOVO IN THE NEWSPAPER \\ „POLITIKA”, AS A MYTH STRENGTHENING POLITICAL \\ POSITION OF KING ALEKSANDER KARADJORDJEVIĆ
}

\author{
Summary
}

The battle of Kumanovo (23 $3^{\text {rd }}-24^{\text {th }}$ October 1912) is considered one of the most important battles of the First Balkan War. Besides the military success, which was opening of the way to so-called Southern Serbia, as great, if not grater was the moral victory of Serbian army. This battle was the first major test of the real strength and value of Serbian army. The victory became an invaluable asset which lifted their morale. It is not a coincidence, that it was defined as the revenge for a battle of Kosovo.

Undoubtedly, the biggest winner of the battle was the heir to the throne, Prince Aleksander Karadjordjević, commander of the First Army, which launched main attack on Turkish positions. Although the commander-in-chief of the Serbian army, during both Balkan wars, was the chief of staff, general 
Radomir Putnik, it was his subordinate, a mere 24 years-old Prince Aleksander, who gained a title of "the great liberator of the Serbs". The success of the Serbian army achieved in this and the subsequent battles of the Balkan wars, and prince's activity during the Great War (since $24^{\text {th }}$ June 1914 he was a Regent of the Kingdom of Serbia) became events, which brought him a great prestige.

It seems, that Aleksander was perfectly aware of that, and tried to strengthen his image as an honest and honorable soldier fighting in defense of his homeland and for the liberation of all South Slavs. As it turned out it was an effective way of obtaining sympathy subjects, the way, which began to be used on a larger scale after taking the throne by Aleksander Karadjordjević (16 $6^{\text {th }}$ August 1921).

However, this task would be difficult without the support of the press, which in the early $20^{\text {th }}$ century was still definitely the most popular and most accessible medium of information. The largest and most popular newspaper in the Kingdom of Serbs, Croats and Slovenes (since 1929 Yugoslavia) was the daily "Politika".

Despite the widely proclaimed political neutrality, the newspaper supported the official political line of the king and government. A very interesting aspect of this activity is its way of presenting events associated with the commemoration of the battle of Kumanovo.

The cultivation of the so-called "myth of Kumanovo" was important aspect of king's Aleksander policy, who in the face of ongoing problems and disputes in the internal policy of the country, wanted to be seen as "unifier", soldier and hero, who was not interested in political games. Much of his subjects perceived him exactly in that way. 
